
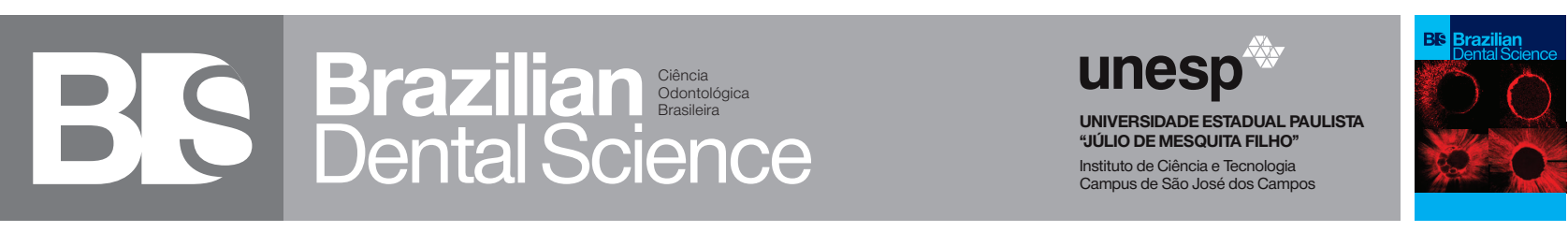

\title{
Comparative study of some mechanical properties of cobalt chromium and polyether ether ketone thermoplastic removable partial denture clasps: an In-vitro Study
}

\author{
Estudo comparativo de algumas propriedades mecânicas dos grampos parciais removíveis termoplásticos removíveis \\ termoplásticos de cobalto cromo e éter cetona: um estudo in vitro \\ Rady EL-BAZ ${ }^{1}$, Mostafa FAYAD ${ }^{2}$, Mohamed ABAS ${ }^{3}$, Ahmad SHOEIB ${ }^{4}$, Mohammed Moustafa GAD ${ }^{5}$, Mohamed Ahmed HELAL ${ }^{6}$ \\ 1 - Removable Prosthodontics Department - Faculty of Oral and Dental Medicine - Al-Azhar University - Cairo - Egypt. \\ 2 - Removable Prosthodontics Department - Al-Azhar University - Faculty of Oral and Dental Medicine - Cairo - Egypt. Substitutive Dental \\ Science Department, College of Dentistry, Taibah University, Saudi Arabia. \\ 3 - Dental Biomaterials Department - Al-Azhar University - Faculty of Oral and Dental Medicine - Cairo - Egypt. \\ 4 - Removable Prosthodontics Department - Al-Azhar University - Faculty of Oral and Dental Medicine - Cairo - Egypt. \\ 5 - Substitutive Dental Sciences Department, College of Dentistry, Imam Abdulrahman Bin Faisal University, Dammam, Saudi Arabia. \\ 6 - Removable Prosthodontics Department - Faculty of Oral and Dental Medicine - Al-Azhar University - Cairo - Egypt.
}

\section{ABSTRACT}

Objective: was to evaluate the retentive force, fatigue resistance and deformity of clasps made from two materials cobalt chromium and poly ether ether ketone (PEEK). Material and Methods: sixteen models were fabricated,each one having lower $1^{\text {st }}$ molar. Models were divided into two groups according to materials, group I (GI) for cobalt chromium (Co-Cr) and group II (GII) for PEEK. Each testing models and its clasps were mounted inside universal testing machine, the retention was measured by applying withdrawal force to it by this machine at $5 \mathrm{~mm} / \mathrm{min}$. The Fatigue resistance is measured by the reduction in retention through repeated insertion and removal cycles using robota chewing simulator. Removal and insertion cycling of clasps was carried out for $360,730,1080,1,440,2,116$ and 2,880 cycles (corresponding to $3,6,9,12,18$ and 24 months of simulated clinical use of a RPD) to simulate the fatigue resistance test. Deformity was measured before and after each cycling using a digital micrometer. Statistical analysis was done by 2-way-ANOVA test to detect significance effects of each variable. Results: Retention and fatigue resistance, after 360,

\section{RESUMO}

Objetivo: o objetivo foi avaliar a força de retenção, a resistência à fadiga e a deformidade dos gramposfabricados com dois materiais diferentes: cromo-cobalto (Co-Cr) e poliéter-éter-étercetona (PEEK). Materiais e métodos: dezesseis modelos foram confeccionados, cada um com $1^{\circ}$ molarinferior. Os modelos foram divididos em dois grupos de acordo com o material: grupo I Co- $\mathrm{Cr}$ egrupo II para PEEK. Cada modelo de teste universal e seus grampos foram montados em umamáquina de teste universal. A retenção foi medida aplicando força de retirada por esta máquinaa $5 \mathrm{~mm} / \mathrm{min}$. A resistência à fadiga foi medida pela redução na retenção através de ciclosrepetidos de inserção e remoção usando um simulador do ciclo de mastigação. $\mathrm{O}$ ciclo deremoção e inserção dos grampos foi realizado por 360, 730, 1080, 1.440, 2.116 e 2.880 ciclos (correspondendo a 3, 6, 9, 12,18 e 24 meses de uso clínico simulado de um RPD) para simularo teste de resistência à fadiga. A deformidade foi medida antes e após cada ciclo, usando ummicrômetro digital. A análise estatística foi realizada pelo teste ANOVA de 2 fatores paradetectar os efeitos de significância de cada variável. Resultados: A retenção e a resistência àfadiga após 360, 730, 1080, 1.440, 2.116 e 2.880 
$730,1080,1,440,2,116$ and 2,880 cycles totally the difference between Co-Cr and PEEK groups was statistically non-significant $(\mathrm{P}=0.0980>$ 0.05) where (Co-Cr $>$ PEEK). Deformation results, regardless to evaluation time, Co-Cr group recorded statistically significant higher deformation mean value than PEEK group $(\mathrm{P}=0.008<0.05)$.Regardless to material group, deformation mean value changed nonsignificantly by time $(P=0.2882>0.05)$. Conclusion: PEEK clasps $(1.0 \mathrm{~mm}$ in cross section diameter) engage $0.50 \mathrm{~mm}$ undercut provide sufficient retention nearly similar that of Co-Cr clasps.

\section{KEYWORDS}

Flexible clasps; polyether ether ketone, PEEK; thermoplastic resin; Partial Denture. ciclos entre os grupos Co-Cr e PEEK nãomostrou diferença estatisticamente significativa ( $\mathrm{p}=$ 0,0980\&gt; 0,05), onde (Co-Cr\&gt; PEEK). Paraos resultados da deformação, independentemente do tempo de avaliação, o grupo Co-Crregistrou um valor médio de deformação maior, com diferença estatística significativa, quandocomparado com o grupo PEEK ( $\mathrm{p}=0,008$ \&lt; 0,05). Independentemente do grupo de material, ovalor médio da deformação foi alterado de forma não significativa pelo tempo $(\mathrm{p}=0,2882 \& g t ; 0,05)$. Conclusão: os grampos PEEK (1,0 mm de diâmetro da seção transversal) engatam $0,50 \mathrm{~mm}$ retenção quase semelhante à dos grampos Co-Cr.

\section{PALAVRAS-CHAVE}

Fechos flexíveis; Poliéter-éter-cetona (PEEK); Resina termoplástica; Prótese Parcial.

\section{INTRODUCTION}

$\mathrm{R}$ emovable Partial Dentuers (RPDs) are considered one of the most important way for replacement of missing natural teeth. RPDs must be have Sufficient retention, flexibility and esthetics which are considered as the most important factors affecting their clinical success. The retentive clasp arms of the direct retainers must be flexible and should retain the RPD satisfactorily without not unduly stress abutment teeth or be permanently deformed during service. Direct retainers of the RPD that were constructed from elastic materials demonstrated a higher resistance to retention loss [1].

The most common metal alloy used for construction of the direct retainers of RPDs is a Co-Cr, also other alloys as gold, titanium and round wrought wire can be used for fabrication of the direct retainer [2]. Metallic RPD has a big esthetic problem many methods have been carried out to overcome this problem such as etching the clasp arm and coating it with a layer of tooth-color resin, and lingual retention design [3]. Recently thermoplastic resins have been introduced into the market, direct retainers fabricated in a tooth-colored material and constructed from polyoxymethylene (POM), also the PEEK and polyetherketonketon (PEKK) have been used to enhance the esthetic of metal direct retainer assemblies of RPD [4]. Polyetheretherketone (PEEK) is a synthetic, tooth colored polymeric material that has been used as a biomaterial in orthopedics for many years $[5,6]$. PEEK can be used for patients allergic to metals, or who dislike the metallic taste, and the unpleasant metal display of the denture framework and retentive clasps [7].

The fatigue of a denture clasp is based on the its constant deflection during insertion and removal of the RPD. Clasp fatigue adversely affected the retentive properties of RPDs, the permanent deformation of clasps can cause loss of retention [8-11].

The fatigue behavior of the direct retainer is affected by its flexibility so the fatigue behavior of clasps made from PEEK may differ from that made from Co-Cr alloy [12,13].

The long-term retentiveness of metal and the thermoplastic resin clasps were not clear [817], and detailed analysis of the fatigue behavior of these clasps seems appropriate. Therefore, this 
report was conducted to compare the retentive forces, fatigue resistance and deformation of PEEK clasps and Co-Cr clasps.

\section{MATERIALS AND METHODS}

For this study sixteen natural lower first molar teeth were collected, cleaned and examined to ensure that only intact non-carious non-mottled enamel was present. Laboratory custom made metallic mold (30 $\mathrm{mm}$ in length, $20 \mathrm{~mm}$ in width, and $25 \mathrm{~mm}$ in height) was used for fabrication the testing models. The testing models were made from self-cure acrylic resin (Acrostone, Egypt) blocks with a natural tooth embedded in each model vertically. The testing models were divided into two groups according to the tested material: GI having CoCr clasps (Kera C, Eisenbacher Dentalwaren ED GmbH, Germany) and GII having PEEK clasps (Bio-HPP, Bredent, Senden, Germany). The abutment of the testing model was surveyed to ensure that there were adequate undercuts 0.02 inch. Tooth preparation was performed to provide rest seat.The laboratory models were duplicated into investment models (Calibra-M, Protechno, Spain) by using silicone duplicating material (Dupliflex, Protechno, Spain).On the investment models, cast Co-Cr alloy and PEEK material frameworks with Ackers clasps were constructed as following:

Half-round cross section (with $1.0 \mathrm{~mm}$ in thickness) Aker clasp wax pattern (Polywax, Bilkim, Izmir, Turkey) was used to construct the wax patterns of the frameworks. According to the clasp and framework material each group was divided into two groups, each group contained eight testing models, GI for Co- Cr clasp material and GII for PEEK clasp material.

Cast Co-Cr alloy frameworks with Aker clasps of GI were constructed as conventional manner, then finished and polished.

For GII the steps of the injection molding process of the PEEk were carried out usual maner to construct the PEEK Aker clasps and frameworks.
After that the framewroks of GI and GII were tried on the models and were considered to be suitable for testing when the occlusal rests fit well in their rest seats, the retainers were in contact with the abutments, and the positive part of the framework rested on the testing model.Each clasp and its model were mounted on a Universal testing machine (Instron ${ }^{\circledR} 3345$, Instron (4)Co. Ltd, Norwood, MA) as shown in Figure 1.

Retention of each clasp at pre-test (Baseline) was measured by applying withdrawal force to it by this machine at $5 \mathrm{~mm} / \mathrm{min}$. To perform the fatigue test, through removal and insertion cycling, ROBOTA chewing simulator integrated with thermo-cyclic protocol operated on servo-motor (Model ACH-09075DC-T, ADTECH TECHNOLOGY CO., LTD., GERMANY) was used. Each clasp specimen was then placed on the corresponding abutment and fixed to the upper part of machine with vertical rod. The test conditions were maintained at room temperature $\left(25 \pm 2{ }^{\circ} \mathrm{C}\right)$ and wet condition. Removal and insertion cycling of clasps was carried out for $360,730,1,080,1,440,2,116$ and 2,880 cycles (corresponding to $3,6,9,12$, 18 and 24 months of simulated clinical use of a RPD) $[9,15]$ to simulate the fatigue resistance test ( Figure 2).

For studying deformity the distance between 2 reference points on the tips of the retentive and reciprocal arms of each clasp was measured before and after each removal cycles using a digital micrometer (Digimatic Micrometer Mitotoyd, Japan) with a resolution $0.001 \mathrm{~mm}$. The data of the retentive force magnitudes at different intervals, fatigue resistance and deformity were tabulated and subjected to statistical analysis. Data analysis was performed in several steps. Initially, descriptive statistics for the results of each group. 2-way-ANOVA test and multi-factorial ANOVA test was performed to detect significance effects of each variable (material group, tooth support and mechanical aging). Also Paired t test and unpaired t test was done between subgroups. Statistical analysis was performed using Graph Pad Instat (Graph 
Pad, Inc.) for Windows. P values $\leq 0.05$ are considered to be statistically significant in all tests.

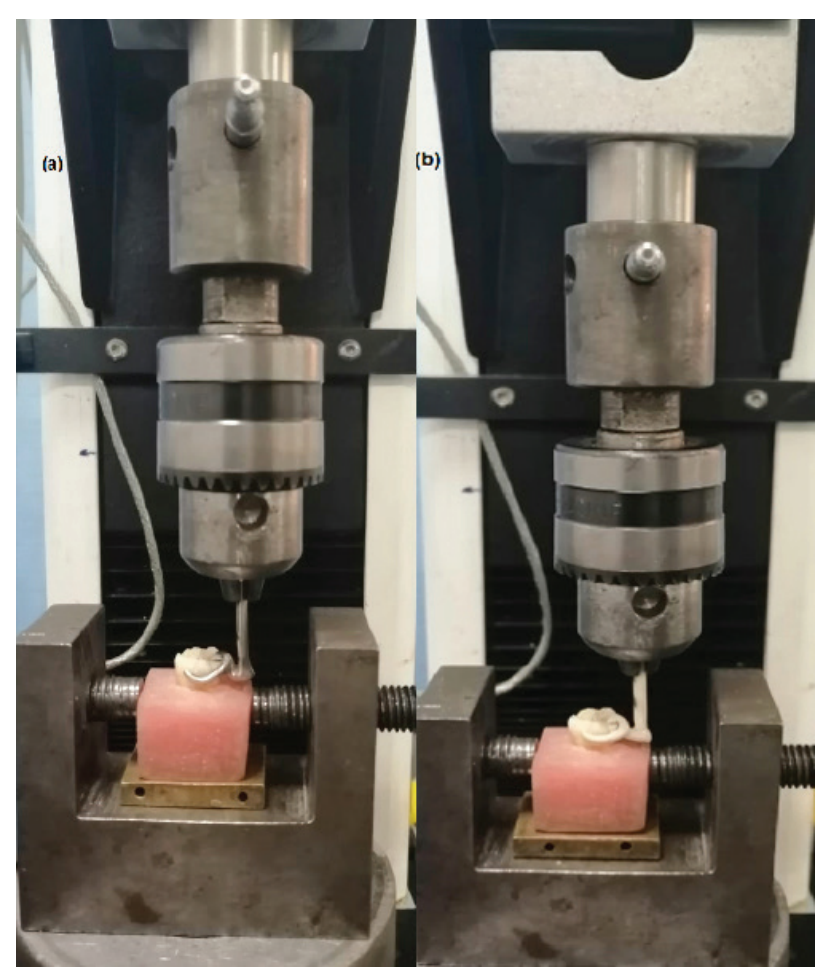

Figure 1 - Each clasp and its model were mounted on the universal testing machine, (a) Co-Cr clasp, (b) PEEK clasp.

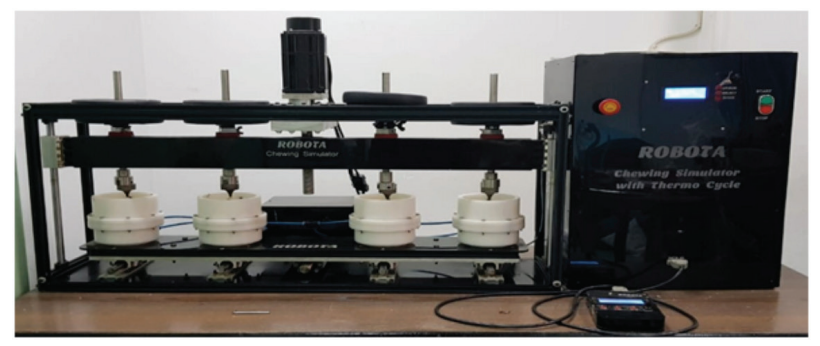

Figure 2 - Each clasp and its models were mounted on the chewing simulator device.

\section{RESULTS}

The results were analyzed using Graph Pad Instat (Graph Pad, Inc.) software for windows. A value of $\mathrm{P} \leq 0.05$ was considered statistically significant. Continuous variables were expressed as the mean and standard deviation.

\section{Retention and Fatigue Resistance}

Table I shows the retention mean values of GI were decreased significantly from baseline to 24 months evaluation time as indicated by one-way ANOVA test $(\mathrm{P}<0.05)$. Pair-wise Tukey's post-hoc test showed non-significant (P $>0.05$ ) difference only between baseline and 3 months. Also the the retention mean values of GII were decreased significantly from baseline to 24 months evaluation time as indicated by one-way ANOVA test $(\mathrm{P}<0.05)$. Pair-wise Tukey's post-hoc test showed non-significant ( $p>0.05$ ) differences only between baseline and 3 months, baseline and 6 months, and 3 months and 6 months. Regarding to \% change, totally the difference between GI and GII was statistically non-significant $(\mathrm{P}=0.0980>0.05)$ where (GI > GII).

Table I - Descriptive statistics of retention results for both groups as function of evaluation time

\begin{tabular}{|cccccc}
\hline Group & Time & Mean & SD & Minimum & Maximum \\
\hline & Baseline & 22.6875 & 2.467374 & 19.9725 & 26.625 \\
\hline 3 months & 21.83644 & 1.103969 & 20.3205 & 23.66 \\
\hline 6 months & 20.75 & 0.128695 & 20.5675 & 20.9325 \\
\hline PEEK & 9 months & 14.31438 & 1.586558 & 11.775 & 16.125 \\
\hline 12 months & 11.19875 & 0.665219 & 10.075 & 12.0175 \\
\hline 18 months & 7.6825 & 1.133814 & 6.225 & 9.575 \\
\hline 24 months & 4.531875 & 1.202503 & 2.7025 & 6.2 \\
\hline Baseline & 36.0405 & 1.098187 & 34.1025 & 37.512 \\
\hline 3months & 34.27 & 0.401189 & 33.595 & 34.745 \\
\hline 6 months & 25.89475 & 1.080684 & 24.1695 & 27.36875 \\
\hline Co-Cr & 9 months & 23.2275 & 0.719953 & 21.95 & 23.9375 \\
\hline 12 months & 15.65438 & 0.177689 & 15.325 & 15.8275 \\
\hline 18 months & 11.275 & 1.542968 & 9.25 & 13.825 \\
\hline 24 months & 8.60625 & 0.959997 & 7.15 & 10.175 \\
\hline & & & & \\
\hline
\end{tabular}




\section{Clasp Deformation results}

Table II shows the deformation mean values of GI were changed significantly from baseline to 24 months evaluation time as indicated by one-way ANOVA test $(\mathrm{P}=0.0478$ $<0.05)$ where the highest mean value recorded after 6 months $(1.27675 \mathrm{~mm})$ while the lowest recorded after 3 months $(0.353 \mathrm{~mm})$.

Also the deformation mean values of GII were changed non-significantly from baseline to 24 months evaluation time as indicated by oneway ANOVA test $(\mathrm{P}=0.05)$ where the highest mean value recorded after 24 months (1.158403 $\mathrm{mm}$ ) while the lowest recorded after 6 months (0.195972 mm).

Totally regardless to evaluation time, GI recorded statistically significant higher deformation mean value than GII as demonstrated by two-way ANOVA ( $\mathrm{P}=$ $0.008<0.05)$. Totally regardless to material group, deformation mean value channged non-significantly as demonstrated by two-way ANOVA $(\mathrm{P}=0.2882>0.05)$.

Table II - Descriptive statistics of deformation results for both groups as function of evaluation time

\begin{tabular}{|c|c|c|c|c|c|}
\hline Group & Time & Mean & SD & Minimum & Maximum \\
\hline \multirow{7}{*}{ PEEK } & Baseline & 0.459583 & 0.123003 & 0.265 & 0.617778 \\
\hline & 3 months & 0.532792 & 0.70402 & 0.026667 & 1.8945 \\
\hline & 6 months & 0.195972 & 0.181033 & 0.05 & 0.545 \\
\hline & 9 months & 0.956944 & 0.645036 & 0.222222 & 1.87 \\
\hline & 12 months & 0.835 & 0.444994 & 0.18 & 1.55 \\
\hline & 18 months & 0.267986 & 0.160135 & 0.044444 & 0.45 \\
\hline & 24 months & 1.158403 & 0.546744 & 0.322222 & 2.0225 \\
\hline \multirow{7}{*}{$\mathrm{Co}-\mathrm{Cr}$} & Baseline & 1.172778 & 0.236185 & 0.8125 & 1.5475 \\
\hline & 3 months & 0.353 & 0.235201 & 0.045 & 0.772 \\
\hline & 6 months & 1.27675 & 0.690932 & 0.0595 & 2.1 \\
\hline & 9 months & 0.881623 & 0.42837 & 0.081111 & 1.268438 \\
\hline & 12 months & 0.957188 & 0.554238 & 0.115 & 1.72125 \\
\hline & 18 months & 1.259722 & 0.298895 & 0.85 & 1.7 \\
\hline & 24 months & 0.775 & 0.25 & 0.3 & 1 \\
\hline
\end{tabular}

\section{DISCUSSION}

The demand for esthetic dental restorations has been increased due to animportance on physical appearance in modern society.Materials for clasps and frameworks of (RPDs) need to have enoughflexibility for the clasps and rigidity for other framework components. Therefore,Co$\mathrm{Cr}$ is the most popular alloy for the frameworks of RPDs. The biggest disadvantage of CoCr clasps is their poor esthetic appearance. Tooth colored clasps made of thermoplastic resins have been developed to overcome the aesthetic problems. In this study, Co-Cr alloy served as the metal group while PEEK served as the thermoplastic group.

It was found that metal group recorded higher retention mean value thanPEEK group at base line, 3, 6, 9, 12, 18 and 24 months (corresponding to 360, 730, 1,080, 1,440, 2,116, 2,880 ) cycles, which is in agreement with the results of Tannous et al. [11], who compared the retentive force of clasps made from three thermoplastic resins PEEK, PEKK, POM and CoCr alloy by the insertion/removal test simulating 10 years use.Based on the results of this study, the retention forces of the PEEK claspsshowed values clearly inferior to those of Co-Cr alloy which agree with the results of the others $[12,13]$.

Also these results support thr using of the PEEK clasps (1.0 $\mathrm{mm}$ in cross section diameter) to engage $0.50 \mathrm{~mm}$ undercut to provide sufficient retention nearly similar that of Co-Cr clasps.

However Abd-Elrahman et al. [12], stated that "the PEEK clasps should be thicker more than $1.0 \mathrm{~mm}$ (in cross-sectional diameter) when engage a deeper undercut $(0.50 \mathrm{~mm})$ to gain the stiffness of the cast CO-Cr clasps $1 \mathrm{~mm}$ in cross sectional diameter and to obtain a clinically acceptable retention".

As the clasps undergone a constant deformation due to the movements of insertion and removal of the prostheses. Previous studies showed how the fatigue strength of Co-Cr clasps concludes with the loss of retention because of the permanent deformation of the metal. In Sara study, two Co-Cr clasps were fractured by fatigue and deformation while PEEK clasps she did not 
break $[14,15]$. According to Arda et al., although the Co-Cr clasps exhibit deformationand not the clasps of acetalic resins, the retention force of the Co-Cr clasps after their deformation remains higher than that of the acetal clasps, although these latest requirements less force of insertion and removal [16]. Loss of retention of the clasps due to fatigue resistance test was considered as a good indicator of permanent deformation of the clasps [17].

At the end of cycling of the present study there was no significant difference in the retention force between the Cr-Co clasp group and the PEEK clasp group however there was increase in the amount of clasp deformation in the Cr-Co clasps more than the PEEK clasps, these may be due to the amount of wear that might be occurred to the retentive arm of PEEK clasp that led to loss of its retention and non-significant statistical difference between the groups.

\section{CONCLUSION}

In accordance with the limitations of this study, it could be concluded that:

due to lack of statistical difference, it should be considered that PEEK clasps $(1.0 \mathrm{~mm}$ in cross section diameter) engage $0.50 \mathrm{~mm}$ undercut provide the same retention as Co-Cr clasps.

\section{REFERENCES}

1. McKenna G, Tada S, Woods N, Hayes M, DaMata C, Allen PF. Tooth replacement for partially dentate elders: A willingness-to-pay analysis. J Dent. 2016 Oct;53:51-6.D0l: 10.1016/j.jdent.2016.07.006

2. Rodrigues RC, Ribeiro RF, de Mattos Mda G, Bezzon OL. Comparative study of circumferential clasp retention force for titanium and cobalt-chromium removable partial dentures. J Prosthet Dent. 2002 Sep;88(3):290-6.PMID: 12426499

3. ChuCH, Chow TW. Esthetic designs of removable partial dentures. Gen Dent. 2003 Jul-Aug;51(4):322-4.PMID:15055607
4. Eid DM el-S. A new material for partial dentures. An unbreakable thermoplastic resin paraformaldehyde and its Co-polymers. EgyptDent J. 1971 Jan;17(1):1-22.PMID:5281919

5. Singh K, Aeran H, Kumar N, Gupta N. Flexible thermoplastic denture base materials for aesthetical removable partial denture framework. J Clin Diagn Res. 20130ct;7(10):2372-3. doi:10.7860/JCDR/2013/5020.3527.

6. Moldovan 0 , Rudolph H, Luthardt RG. Clinical performance of removable dental prostheses in the moderately reduced dentition: a systematic literature review. Clin Oral Investig. 2016 Sep;20(7):1435-47. D01:10.1007/s00784-016-1873-5

7. Zoidis P,Papathanasiou I,Polyzois G.The Use of a Modified Poly-Ether-EtherKetone (PEEK) as an Alternative Framework Material for Removable Dental Prostheses. A Clinical Report.J Prosthodont. 2016 0ct;25(7):580-584.DOl: 10.1111/jopr.12325

8. YAMAMOTOETC, SATO TP,SILVA JMF2, BORGES ALS, UEMURAES. Retentive force comparison between esthetic and metalclasps for removable partial denture. BrazDentSci, 2017;20:87-93.DOl: 10.14295/bds.2017.v20i3.1431

9. Helal MA1, Baraka OA, Sanad ME, Ludwig K, Kern M. Effects of long-term simulated RPD clasp attachment/detachment on retention loss and wear for two clasp types and three abutment material surfaces. J Prosthodont. 2012 Jul;21(5):370-7. doi: 10.1111/j.1532-849X.2012.00844.x.

10. FuekiK, Ohkubo C, Yatabe M, Arakawal, Arita M, Ino S, etal.. Clinical application of removable partial dentures using thermoplastic resin. Partll:Material properties and clinical features of non-metal clasp dentures. $J$ Prosthodont Res. 2014 Apr;58(2):71-84. do: 10.1016/j.jpor:2014.03.002

11. Tannous F1, Steiner M, Shahin R, Kern M. Retentive forces and fatigue resistance of thermoplastic resin clasps. Dent Mater. 2012 Mar;28(3):273-8. doi: 10.1016/j.dental.2011.10.016.

12. Abd-Elrahman IA, Helal MA, Saqar HM, Abas M. Evaluation of Fatigue Resistance of Acetal Resin and Cobalt-Chromium Removable Partial Denture Clasps. An In-vitro Study:Part 1.J Dent Oral Care Med. 2016;2(3):304. doi: 10.15744/2454-3276.2.304

13. Helal MA, Abd-Elrahman IA, Saqar HM, Salah A, Abas M. Evaluation of Acetal Resin and Cobalt-Chromium Clasp Deformation and Fatigue Resistance in Removable Partial Denture Clasps - An In Vitro Study. J Clin Res Dent 2018;(1):1-5.

14. Alvarez S, Escuin T,ClaramuntR, Ascaso C. Preliminary Study to Compare the Insertion/Removal Force of PEEK and Co-Cr Clasps. Open Journal of Dentistry and Oral Medicine 2017;5.2:11 - 19. doi: 10.13189/ojdom.2017.050201.

15. Helal MA, Baraka OA, Sanad ME, Al-Khiary Y, Ludwig K, Kern M. Effect of clasp design on retention at different intervals using different abutment materials and in a simulated oral condition. J Prosthodont. 2014 Feb;23(2):140-5. doi: 10.1111/jopr.12072.

16. Arda T1, Arikan A. An in vitro comparison of retentive force and deformation of acetal resin and cobalt-chromium clasps. J Prosthet Dent.2005 Sep:94(3):26774. DOI: 10.1016/.jprosdent.2005.06.009

17. Muhsin SA, Hatton PV, Johnson A, Sereno N, Wood DJ. Determination of Polyetheretherketone (PEEK) mechanical properties as a denture material. Saudi Dent J. 2019 Jul;31(3):382-391. DOl: 10.1016/j. sdentj.2019.03.005

\section{Prof. Dr. Mohamed Helal}

(Corresponding address)

Al-Azhar University, Faculty of Dentistry, Department of Removable Prosthodontics, AlmokhyamAldaem St., Nasr Road, 11884 Nasr City, Cairo, Egypt.

Date submitted: 2019 Nov 06

E-mail: mhelal@azhar.edu.eg 